\title{
PUBLIC RELATIONS STRATEGY FOR IMPROVING QUALITY OF SERVICE TO PATIENTS (Qualitative Descriptive Study at Muslimat Ponorogo Hospital)
}

\author{
Aulia Amana Putri \\ Institut Agama Islam Negeri Ponorogo \\ Jl. Puspita Jaya, Jenangan,Ponorogo \\ Email : auliaamana@gmail.com
}

\begin{abstract}
Abstrack: RSU Muslimat Ponorogo focuses on the quality of service to patients. This study aims to determine how the strategy is carried out by public relations. This article uses a descriptive type of research with a qualitative approach. Researchers get data from interviews, observation, and documentation. The results showed that the public relations strategy of the Muslimat Ponorogo Hospital in improving the quality of service to patients was in accordance with the theory presented by the researcher. First, the human relations strategy is to maintain good relations with employees and customers or patients. Second, the community relations strategy is to maintain good relations with the community and communities around the hospital. Third, the media relations strategy is to use mass media, be it print, electronic or new media (internet). Fourth, it was found that the inhibiting factors faced by public relations in improving service quality, such as registration queue problems, lack of parking area, and lack of human resources. Meanwhile, supporting factors were also found, namely the presence of introductory media used, including conventional media, namely radio and television, outdoor media, namely billboards, and new media (internet), namely the internet, social media websites, Facebook, Instagram, and YouTube.
\end{abstract}

\section{Introduction}

In today's era, people are served with various facilities that exist in a company. The company tries to provide facilities and services with various kinds of conveniences and even breakthroughs that are designed in such away. They do various ways so that their company can be known by a wide audience. So that there are many companies that compete to attract public interest. In order to be known by a wide audience, of course, a company needs a public relations or PR function. The existence of this public relations division or department has a very important and crucial role because it becomes a bridge between the company and the public. The public relations department plays a role in crisis management, building public trust, and maintaining the reputation or image of an organization or company. In addition, the public relations department can also be a measure of whether a company is progressing or not.

Basically, public relations is a management function that builds, maintains, and maintains a good and beneficial relationship between an organization and the 
public which can affect the success or failure of the organization. In order for this function to be effective, public relations practitioners must have the ability to communicate and establish good relations with the public. Public relations must be able to create a positive impression of the parties with whom to communicate with the organization. ${ }^{1}$

Meanwhile, in order to create and develop a positive image, public relations must be able to be a good informant for the company. This is because currently, the public is more selective in choosing companies, especially companies engaged in services. One of the companies engaged in services is a hospital.

Hospital is an institution that organizes and provides complete individual health services. These health services include inpatient, outpatient, and emergency services. According to WHO (World Health Organization), the hospital is an inseparable part of a social and health organization that has the function of organizing and providing complete (plenary) services to the community (comprehensive), disease healing (curative), and disease prevention (preventive). ${ }^{2}$

Hospitals are companies that must try to maintain the quality of their services. This is because the community pays great attention to the quality of the service. The hospital is a health institution where health service problems are the most frequent complaints or complaints from patients or the public. Complaints from the community usually arise due to negligence or error of hospital officials in providing health services to the community as patients. Therefore, improving service quality is very important in institutions such as hospitals. As a health facility that provides health services to the community, hospitals are required to provide quality services in accordance with established standards and can reach all levels of society.

Talking about service quality, the size is not only determined by the serving party but more determined by the party being served, because they are the ones who enjoy the service so that they can measure the quality of service based on their expectations in fulfilling their satisfaction. ${ }^{3}$ Each person will assess the quality of service based on different standards or characteristics. The community or patients see quality service as a health service that can meet their perceived needs and the treatment provided by hospital staff in a manner that is polite, timely, responsive, and able to cure their complaints and prevent the development or spread of the patient's disease.

This study is focused on examining public relations strategies in improving the quality of service to patients at the Muslimat Ponorogo General Hospital.

\footnotetext{
${ }^{1}$ Rachmat Kriyantono, Teori Public Relations Perspektif Barat dan Lokal: Aplikasi Penelitian dan Praktik (Jakarta: Prenadamedia Group, 2014), 217.

${ }^{2}$ Irwandy, Efisiensi dan Produktifitas Rumah Sakit: Teori dan Aplikasi Pengukuran dengan Pendekatan Data Envelopment Analysis (Makasar: CV. Social Politic SIGn, 2019), 13.

3 Atep Adya Barata, Dasar-Dasar Pelayanan Prima: Persiapan Membangun Budaya Pelayanan Prima untuk Meningkatkan Kepuasan dan Loyalitas Pelanggan (Jakarta: PT. Elex Media Komputindo, 2003), 36.
} 
Ponorogo Muslimat General Hospital is one of the famous private Islamic hospitals in Ponorogo. This Muslimat General Hospital is located at Jl. General Ahmad Yani No. 155 Ponorogo, East Java. Researchers chose RSU Muslimat Ponorogo as the research location because this hospital is the only hospital-owned by Muslimat Nahdlatul Ulama (NU) in the ex-Residency of Madiun and the Ponorogo branch. Where do we know that NU is one of the largest Islamic organizations in this country. A part from that, it is also because the hospital is located in a strategic place, and is easily accessible to the community, especially for researchers, so that they can access and conduct research intensively.

This research is important because researchers want to see how the strategies carried out by public relations RSU Muslimat Ponorogo in improving the quality of service to patients. Because along with the emergence of polemics in the community, that in services sometimes there are still problems that arise, both in terms of infrastructure and even treatment aspects. From those few problems, basically, it will affect the positive image and quality of hospital services itself.

Meanwhile, as a hospital which is one of the providers of public health services, it should pay attention to the quality of service which is an important service for every hospital. Because the image will be formed through the quality of service. The better the services provided, the better the image of the hospital in front of the public. Likewise, if the service provided is poor, it will have a negative impact on the hospital. Thus the role of public relations is very important for the Muslimat Ponorogo General Hospital to maintain and improve its image and to establish good relations between the company and the public. In addition, the development of the Ponorogo Muslimat General Hospital certainly cannot be separated from the existence of a public relations strategy in improving the image of service quality to patients.

This research uses a descriptive type of research with a qualitative approach. The descriptive method is intended for exploration and clarification of a social phenomenon or reality, by describing a number of variables relating to the problem and the unit under study. ${ }^{4}$ Qualitative research aims to gain a general understanding of social reality from the views or perspectives of participants. This understanding is not determined in advance but is obtained after analyzing the social realities which are the focus of the research and then a conclusion is drawn in the form of a general understanding of these facts. ${ }^{5}$

The researcher used a qualitative descriptive approach because the researcher wanted to describe the results of the study using written words and describe the results of the interview from the research object. In this study, the

\footnotetext{
${ }^{4}$ H. Ardial, Paradigma dan Model Penelitian Komunikasi (Jakarta: Bumi Aksara, 2015), 262.

${ }^{5}$ Rosady Ruslan, Metode Penelitian Public Relations dan Komunikasi (Jakarta: PT

Rajagrafindo Persada, 2010), 215.
} 
researcher described the public relations strategy of the Muslimat Ponorogo General Hospital in improving the quality of service to patients.

\section{Human Relations Strategy of Muslimat Ponorogo Hospital in Improving Service Quality to Patients}

Improving the quality of service to patients at the Muslimat Ponorogo Hospital certainly requires the right process and strategy. This strategy needs to be done so that public relations activities in improving and maintaining service quality always go according to plan. A strategy is a series of activity designs that describe how a company must operate to achieve its objectives. Therefore, the strategy needs to be structured in such a way as to achieve the stated goals.

The form of public relations strategy carried out by the Ponorogo Muslimat General Hospital is manifested in several stages, one of which is the use of a human relations strategy, which is to maintain a special relationship between fellow citizens in the company informally, as a human (humanly). ${ }^{6}$ Human relations is maintaining and maintaining good relations between fellow humans. These relationships include internal and external relationships. Internal relationships, namely relationships between fellow employees, relationships with superiors and subordinates and vice versa. Meanwhile, external relations are establishing good relations with the community around the Ponorogo Muslimat Hospital. Without a good relationship with all of them, course the existence of the Ponorogo Muslimat Hospital will not be accepted by the community.

In maintaining relationships with employees (employee relations), RSU Muslimat Ponorogo held activities aimed at increasing knowledge and improving the quality of employees, one of which was by holding training called in-house training (IHT). This in-house training includes in-house training for handling maternal and neonatal emergencies, in-house training for triage, in-house training for basic life support, and in-house training on effective communication. In-house training for handling maternal and neonatal emergencies is to improve services and prevent deaths in emergency management. For in-house training, triage is in order to develop expertise in the medical field and its application in the field. Meanwhile, basic life support in-house training is to prepare employees who are responsive to emergencies, which can happen anytime and anywhere. As well as in-house training, effective communication is one important aspect in order to improve services and increase the soft skills of all employees of the Muslimat Ponorogo Hospital.

Ponorogo Muslimat Hospital also holds special coaching activities for employees which are carried out regularly every month. For the first month, there is spiritual training from the hospital director, while in the second month there is a special recitation for employees. Not only that, but the hospital also holds gymnastic activities, leisurely walks, and outbound activities with employees. Gymnastics

${ }^{6}$ Setyawati, "Strategi Public Relations dalam Mempertahankan Citra Halal Tourism di Syariah Hotel Solo", 24-25. 
activities are held once every 2 weeks and involve the community so that it can be a means of building relationships with the surrounding community as well.

Meanwhile, in order to maintain relationships with customers or patients (customer relations), it is manifested in various activities that lead to social care. Such as home visits for post-hospitalized patients, treatment for the duafa community, mass circumcision or circumcision for pious children, and cost relief for poor patients. The home visit for post-hospitalized patients is carried out every 3 months. This home visit activity can be called a service visit whose purpose is to see the extent of the patient's development or condition. In this activity, the hospital also provides social care, for example, such as providing compensation in the form of basic food and financial benefits.

Related to treatment for the poor is by providing compensation and free health check services. Meanwhile, the mass circumcision activity or circumcision for pious children is carried out once a year for free and takes place in the hospital. Information about this mass circumcision is disseminated through a Facebook account, then the public can register via the hospital phone number. One of the activities is to introduce the Ponorogo Muslimat Hospital to the wider community. In addition, regarding cost waivers for patients who cannot afford or duafa, the source is taken from the Charity Zakat, Infaq, and Alms Foundation (LAZIS) employees of RSU Muslimat Ponorogo.

Thus it can be said that a public relations person must maintain good relations with all parties or what is called human relations, both with employees (employee relations) and customers (customers). By maintaining good relationships with employees, their goodwill, cooperation, and trust can be fostered and maintained. ${ }^{7}$ In addition, the success of a company, especially hospitals in improving service quality is through good relationships with customers. Because of that, regular customers must always be "held", not to let their attention shift and become customers of other companies. ${ }^{8}$

\section{Community Relations Strategy of Muslimat Ponorogo Hospital in Improving Service Quality to Patients}

The community relations strategy undertaken is to specialize in the audience in the people who live or are around the company (factory). The company emphasizes this aspect in its public relations activities because it is in a community environment, where community understanding and support is needed to maintain the company's goals. ${ }^{9}$ Therefore, the Ponorogo Muslimat Hospital needs to maintain good relations with the community and community around the company as well. Building and fostering good relationships with the community and communities in Ponorogo and

\footnotetext{
${ }^{7}$ Hadiati S, Public Relations Perspektif Teoritis dalam Menjalin Hubungan dengan Publik,

${ }^{8}$ Effendy, Human Relations \& Public Relations, 150-151.

${ }_{9}^{9}$ Morissan, Manajemen Public Relations: Strategi Menjadi Humas Profesional, 32.
} 
its surroundings has made Ponorogo Muslimat Hospital increasingly recognized by the wider community. This needs to be done because to grow a positive image in front of the public.

One of the activities carried out by the public relations of the Ponorogo Muslimat Hospital is related to the Ponorogo branch of the Nahdlatul Ulama as the owner of the hospital, namely by participating in the Harlah NU and Muslimat harlah activities. In addition to these activities, the hospital also holds activities related to the wider community, especially the community, namely the hypertension club, health checks with the Terios car club, and service outreach at meetings of Muslim women in NU. Related to the hypertension club activity, namely by gathering elderly people at residents' homes, health centers, or village halls, then the hospital comes and provides health education. If the club is hypertensive, then the material presented is also related to hypertension. Meanwhile, the activities for other communities are the general community, such as meetings of Muslim women. During the meeting, the hospital conveyed the socialization of services at the hospital as well. Not only that, but the Ponorogo Muslimat Hospital also held activities related to the outside community to gain community understanding and support. This is very necessary to maintain company goals. Activities carried out by public relations include social service in sima'an Wednesday pahing throughout Ponorogo every 35 days. In this activity, there was free medical treatment for the congregation who followed sima'an Wednesday pahing. Thus it can be said that the public relations of the Muslimat Ponorogo Hospital also implements a community relations strategy to improve the quality of service to patients.

\section{Media Relations Strategy of Muslimat Ponorogo Hospital in Improving Service Quality to Patients}

Media relations or often referred to as press relations is an effort to publish or broadcast a message or information in order to create knowledge and understanding to the audiences of a company concerned. Media relations occupy an important position in the work of a public relations officer because the mass media are the goalkeepers in controlling the information flowing to society. ${ }^{10}$ Media relations is very important for an agency, especially RSU Muslimat Ponorogo because the media is a bridge to control information to the public and is able to create understanding and knowledge about hospitals in front of the public.

Some of the activities carried out by the public relations of the Ponorogo Muslimat Hospital involve both print and electronic media, such as health seminars that target health workers, consisting of doctors, nurses, and midwives. This program, which is routinely carried out once a year, was published in the Mataraman weekly media. Apart from that, a talk show on Aswaja radio was conducted by specialist doctors and nursing staff. Not only that, the Ponorogo

${ }^{10}$ Darmastuti, Media Relations: Konsep, Strategi dan Aplikasi, 40-42. 
Muslimat Hospital also had time to make the NU and Muslimat harlah sayings on Sakti TV.Other activities carried out by the public relations of the Muslimat Hospital

Ponorogo is a communication in the form of a publication that aims to publish the hospital or the event that is being held. This publication activity is carried out through internet social media. The social media used by the Ponorogo Muslimat Hospital are the website, Facebook, YouTube, Instagram, and Twitter. Therefore, it can be said that public relations RSU Muslimat Ponorogo also implements a media relations strategy to improve the quality of service to patients.

With the many activities or publications carried out through media relations, the Ponorogo Muslimat Hospital will increasingly have a good image in the eyes of the Ponorogo community and the wider community. The strategy carried out by the public relations of the Muslimat Ponorogo Hospital is already good, but it still needs to be improved again in order to maintain the company in the present. In addition, the media relations activities carried out above must continue to be carried out, because this activity aims to make all information and activities available at the Ponorogo Muslimat Hospital known to the public and bring a positive image, without mass media and publications, the hospital would not be well known to the public.

\section{Four Steps of Public Relations Strategy of Muslimat Ponorogo Hospital in Improving the Quality of Service to Patients}

\section{Public Relations RSU Muslimat Ponorogo Determining Problems}

The first step that must be done by public relations RSU Muslimat Ponorogo before compiling a work program, especially in improving the quality of service to patients is to determine in general the problems that often occur in the hospital. These problems include services that cannot yet be served at the Ponorogo Muslimat Hospital and must collaborate with third parties as partners, such as CT scans, dialysis, and chemotherapy. In addition, there are also problems with the registration queue and parking space. The lack of parking areas is still an obstacle from year to year for the hospital. On the other hand, the parking lot is not the hospital management who manages it, but from outside parties or the surrounding community.

Meanwhile, regarding the problems that often arise in the hospital, especially regarding patient complaints, the public relations of the Muslimat Ponorogo Hospital provides facilities to accommodate these complaints. These facilities include an SMS center, a questionnaire, a suggestion box, a satisfaction box, and a message and impression board. The critique and suggestion boxes are on each floor or area, and the person in charge of service complaints is divided into 2, the 1st floor is from the midwifery, and the 2nd and 3rd floors are handled by the head of the nursing department. Then for the questionnaire given to the patient when finished treatment in the hospital. While taking the suggestion box is done a maximum of 1 
week. With the facilities to accommodate the patient's complaints, of course, it will be very influential with the services provided to patients. On the other hand, these facilities can be used as a benchmark for the hospital regarding what services must be maintained and addressed.

\section{Public Relations RSU Muslimat Ponorogo Planning and Compiling Programs}

The second step that must be done by public relations is compiling a work program. In this case, the problems that have been determined in the first step are used as a reference for developing programs, objectives, actions, and communication strategies. Public relations RSU Muslimat Ponorogo has steps that will be taken in overcoming the problem of queues and lack of parking space in the hospital area. Regarding the queue problem, there will be a solution to the registration unit. For patients who go to clinic clinics, the registration is behind, namely in the polyclinic area. Meanwhile, emergency room patients and inpatient registration area at the front as before.

Not only that, to solve the queue problem, public relations at the Muslimat Ponorogo Hospital also created an online registration application, so it can reduce the accumulation of patients at the registration counter. This online application can be directly accessed by old patients, both general and BPJS patients who already have a medical record number. Meanwhile, new patients must come to the hospital first. Meanwhile, regarding the parking area problem, there will be an expansion of the area. Because the hospital program is the development of a new building on the 5 th floor, while the ground floor is for the parking area so that it can reduce the level of parking complaints itself.

\section{Public Relations RSU Muslimat Ponorogo Take Action and Communicate}

After knowing the problems that exist in the hospital and compiling programs that will be carried out to overcome these problems, the next step is to take action and communicate. Regarding problems and education in the service, communication and action will be carried out by the units in the service department.

\section{Public Relations RSU Muslimat Ponorogo Evaluates Work Programs}

The last stage carried out by public relations at the Muslimat Ponorogo Hospital includes an assessment or evaluation of the preparation, implementation, and results of the program that has been implemented. In this case, public relations evaluates the work program by looking at the extent to which program targets can be achieved and what percentage of the program itself is achieved. Regarding this work program, there are several public relations work programs at the Muslimat Ponorogo Hospital from 2018 to 2019 that have not been achieved. An example is the social service program which must be implemented 4 times a year, but only 2 times. In addition, the social service partner program is a medical program that collaborates with other institutions, be it government, private, or community. However, for this partnered social service program, public relations at RSU 
Muslimat Ponorogo only refers to requests, if other agencies submit requests, this partnered social service program will only be implemented.

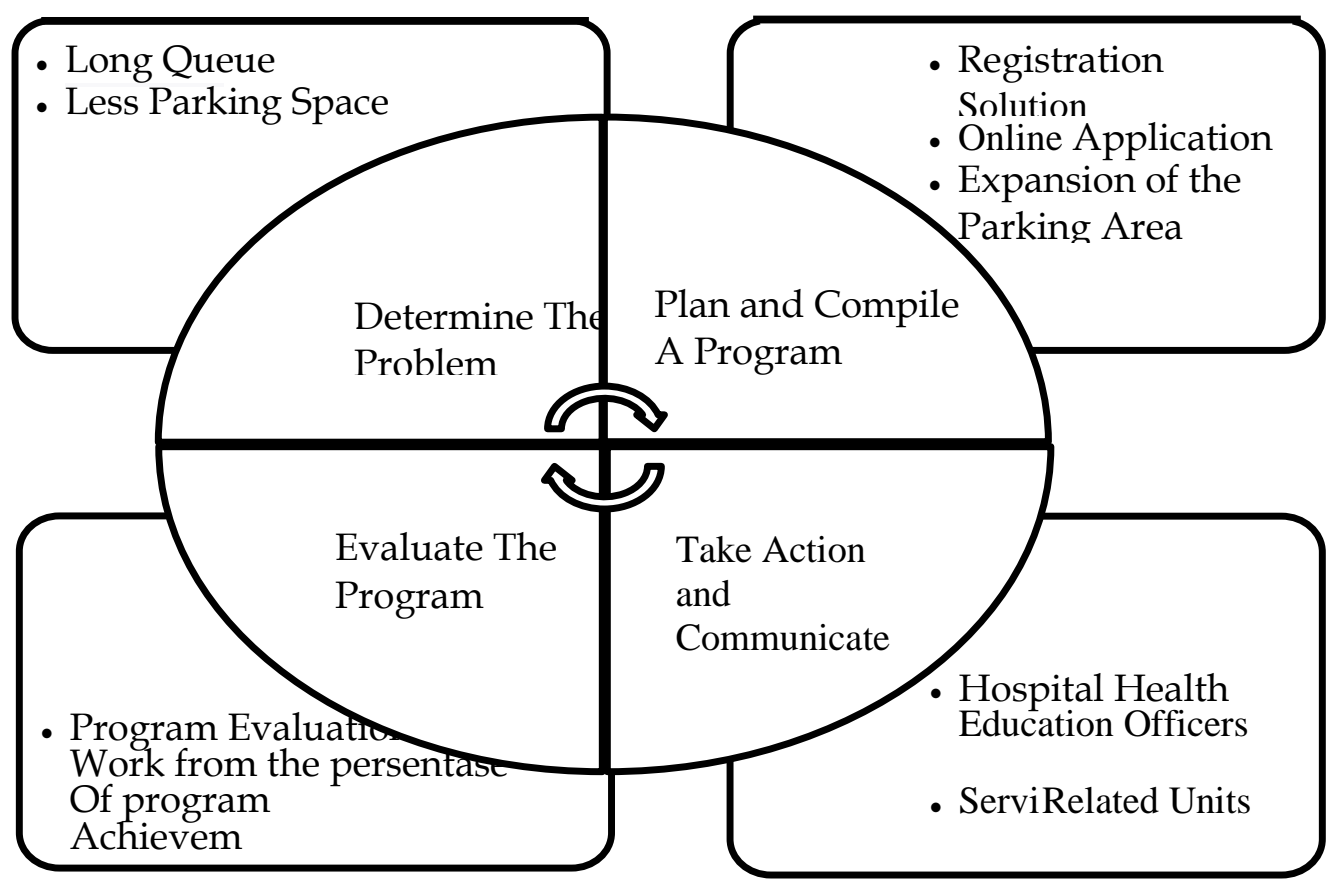

Sumber: OlahanPeneliti

\section{Public Relations Mix of Ponorogo Muslimat Hospital}

\section{Publications}

The public relations strategy of Muslimat Ponorogo Hospital in improving the quality of service to patients is through publication. Publication activities carried out are by conveying messages or information to the public about the hospital. The information conveyed included the domicile of the hospital, existing facilities in the hospital, doctors owned by the hospital, and their working hours, as well as health education. The dissemination of information about the hospital was carried out using various types of media, namely conventional media, new media (internet), outdoor media, and small format media. This is done so that the information can be received by the public properly and quickly.

The conventional media used by the Muslimat Ponorogo Hospital are radio and television. For radio broadcasting media is Asawaja radio. Through the radio, the Ponorogo Muslimat Hospital conducted a talk show or interactive dialogue. As for TV broadcasting media, the Ponorogo Muslimat Hospital has collaborated with Sakti TV. Meanwhile, in using the new media (internet), the Ponorogo Muslimat 
Hospital chose to use internet social media such as the website, Facebook, YouTube, Instagram, and Twitter. Besides using conventional media and new media (internet) to disseminate information to the public, public relations at the Muslimat Ponorogo Hospital also uses outdoor media such as billboards, and small format media such as leaflets or brochures. All forms of media used by public relations at RSU Muslimat Ponorogo run smoothly without significant obstacles, so they can help the promotion activities.

So it can be concluded that the use of several media facilitates as well as helps the process of conveying information about the Ponorogo Muslimat General Hospital to the public. Based on the observations of researchers, the use of digital media is more and more important than conventional media. This can be seen from the social media activities of the Ponorogo Muslimat Hospital. RSU Muslimat Ponorogo has uploaded a lot of digital content on social media accounts, starting from Instagram and Facebook.

\section{Event}

The process of disseminating information to the public by public relations at RSU Muslimat Ponorogo was carried out with several activities, both activities involving internal and external audiences of the hospital. This activity is carried out to build an image of the quality of hospital services in front of the public. Such as walking activities as well as health services whose participants consist of all employees and residents around the hospital. There are also Islamic holiday activities, such as breaking fast together and halal bihalal. Not only that but to publish the Ponorogo Muslimat Hospital there are also social activities and mass circumcision.

\section{News}

Information about the quality of services available at RSU Muslimat Ponorogo is communicated to the public directly or indirectly. Direct communicated messages or information, for example, such as socialization services at meetings of Muslim women in NU. Meanwhile, indirect messages are conveyed using communication media. The message was published in billboards, leaflets, or brochures and posted on social media accounts belonging to the Ponorogo Muslimat Hospital. The message compiled by RSU Muslimat Ponorogo uses language that is straightforward, dense, clear, and persuasive, namely messages containing health education and information about services in the hospital in detail. With this persuasive message, it is hoped that there will be results obtained, namely in the form of changes, both knowledge, attitudes, and behavior of the public, of course, to choose the Ponorogo Muslimat Hospital as a reference.

\section{Corporate Identity}

In order to improve the quality of service, the Ponorogo Muslimat Hospital must build and maintain a positive image of the hospital. When there are complaints that 
are not good from the public, that is where the role of public relations is needed to improve the image of the hospital.

\section{Community Involvement}

RSU Muslimat Ponorogo collaborates with the first facilities, such as health centers, clinics, and family doctors. Not only that, but the hospital also collaborates with insurance parties such as BPJS, both health and employment BPJS, and Jasa Raharja insurance. Meanwhile, the relationship with the media, the hospital collaborates with conventional media, namely radio and television. For radio broadcasting media is Aswaja radio, and for TV broadcasting media, Ponorogo Muslimat Hospital has collaborated with Sakti TV.

RSU Muslimat Ponorogo also tries to build relationships with the community through caring for the community. Such as home visits with these post-treated patients at the hospital, treatment for the dhu'afa community, and mass circumcision. When there are activities such as a series of Ramadan, for example, iftar together and halal bihalal, the hospital also invites the surrounding community. Not only that, for a series of activities for the Republic of Indonesia's Independence Day, the hospital also invited the surrounding community to take a leisurely walk. So it can be said that, in order to improve the quality of service, RSU Muslimat Ponorogo builds a relationship with the public, including stakeholders, the media, the community around the company, and others.

\section{Lobbying and Negotiation}

This stage is a plan both long term and short term assisted by PR in the framework of preparing the required budget. Therefore, to improve the quality of public relations services, RSU Muslimat Ponorogo has long and short term plans. Regarding the short term in seeing the quality of service, each patient or family was given a questionnaire by sampling, they were asked to provide an assessment starting from the start to going home from treatment. because this is related to the need to improve the quality of hospital services. While in the long term, it is social activities. Like free medication, both self-medication and partner treatment. To be independent, all accommodation, both drug costs, medical personnel, and other accommodation are fully borne by the hospital operations. Meanwhile, in partnership, RSU Muslimat Ponorogo collaborates with both government and private institutions.

\section{Social Responsibility}

The responsibilities of RSU Muslimat Ponorogo towards the community or communities around the company, for example in the form of health checks with the Terios car club, and socialization of services at meetings of Muslimat NU women. Not only that, the hospital often holds social service activities on Wednesday for the entire Ponorogo, waivers for the underprivileged people, compensation for dhu'afa, 
and mass circumcision. So that in order to improve the quality of service at RSU Muslimat Ponorogo, the discourse of social responsibility is used by companies to take a joint role and carry out its activities in order to prosper the surrounding community.

\section{Measurement of Service Quality at the Muslimat Ponorogo Hospital}

Hospitals as institutions that provide health services should be managed as well as possible to improve service quality. With the improvement in the level of public education, it has resulted in a tendency to demand better, faster, and more responsive public services. The existence of the hospital itself, both private and government owned and the emergence of health clinics, have resulted in intense competition in providing health services. Therefore, each health service provider agency must be able to improve the quality of its services, so that it can be an option for the community.

One of the strategies used by the hospital is basically to provide quality services and be oriented to patient satisfaction. The quality of service includes aspects of hospital facilities, the role of doctors, nurses, and hospital non-medical staff. This is very important because their performance will determine the quality of service provided to patients. Thus, the authors raise aspects of the form of service as a reference and benchmarks.

The form of a service quality measurement strategy carried out by the public relations of the Muslimat Ponorogo Hospital is manifested in several stages as the researcher describes in theory. The following is the adjustment of the stages or steps for measuring the quality of services carried out by the Public Relations of the Muslimat Ponorogo Hospital, namely:

\section{Tangibles}

Tangibles or physical evidence is the ability of physical facilities and infrastructure as well as the condition of the environment around the Ponorogo Muslimat Hospital as tangible evidence of the services provided. This includes the appearance of physical facilities, equipment, personnel, and communications. As a type D hospital, RSU Muslimat Ponorogo strives to provide the maximum possible health services in accordance with the available facilities and facilities. Until now, the hospital is working together to improve health services through medical services such as emergency departments (IGD), specialist outpatient services, inpatient services, and installation services to support medical services, as the authors have described in Chapter III. The physical facilities are intended to increase patient satisfaction and to facilitate the service process at the Muslimat Ponorogo Hospital so that the principles of effectiveness and efficiency in services to the hospital public will be created.

These physical facilities are also supported by easy access in requesting services at RSU Muslimat Ponorogo. This includes places and locations as well as adequate service facilities, easily accessible to the public, and can take advantage of 
telecommunications and information technology. One of them is the Ponorogo Muslimat Hospital, which provides an online application that can be downloaded via the Playstore. The application is called RSU Muslimat Ponorogo and includes various features that can be accessed, including registration features, doctor schedules, queues, rooms, suggestions, satisfaction surveys, patient information, and education. With this online application, people can easily register at the Ponorogo Muslimat Hospital, they can also access information about the services they want, such as a doctor's schedule and room availability. Apart from using the online application, patients who are going for treatment can also book a room via the hospital phone.

Ease of access to these services is also supported by the comfort of a place to perform services, both in terms of comfort in the treatment room, cleanliness and tidiness. Hospital cleaners always pay attention to the cleanliness of the treatment room every day. Not only that, the officers of the Ponorogo Muslimat Hospital also pay attention to discipline and appearance. They are required to be disciplined, both work discipline and time. In this case, they must be disciplined in all matters, especially in providing services, including inspection hours. Because, this discipline is very important to build trust between patients and officers.Meanwhile, hospital staff must also have a neat appearance, of course, one that is considered comfortable. Not only neat, both doctors, nurses, and their screening services have excellent work uniforms and are worn according to the uniform schedule every day. So it can be said that in measuring the quality of service, RSU Muslimat Ponorogo pays attention to the tangibles dimension which consists of indicators of convenience in the service process, comfort of the place of service, discipline of officers and appearance in serving patients.

\section{Reliability}

A company must-have steps to deal with its customers, especially companies engaged in services such as RSU Muslimat Ponorogo. For this reason, providing accurate, fast, timely, and satisfying services are needed by patients. In this case, to improve the quality of service to patients, RSU Muslimat Ponorogo provides services according to standard operating procedures (SOP), vision and mission, and also hospital philosophy. The officers, whether doctors, nurses, midwives, or medical and non-medical officers are also careful because this is related to patient care.

Thus, in measuring the quality of service must pay attention to the dimension of reliability. In short, this dimension can be interpreted as the ability to provide services accurately, on time, and reliably. So it can be said that in measuring service quality, RSU Muslimat Ponorogo pays attention to the dimensions of reliability which consist of indicators of accuracy, ability, and expertise of officers in serving customers, as well as having clear service standards. 


\section{Responsiveness}

When it is related to the theory that the researcher describes in chapter II, in improving the service quality of the Muslimat Ponorogo Hospital, it has paid attention to the responsiveness dimension. In short, it can be interpreted as the responsiveness or willingness of the Ponorogo Muslimat Hospital to provide good, fast, precise service and convey clear information to patients. Because the advantages possessed by the Ponorogo Muslimat Hospital itself are fast and punctual services. In this case, the hospital also does not differentiate between general patients and BPJS patients, so that when patients come, they are immediately followed up, there is no need to wait long for reasons of BPJS or general patients.

\section{Assurance}

RSU Muslimat Ponorogo in improving the quality of service also pays attention to the dimension of assurance (assurance). In short, it can be interpreted as the knowledge and friendliness of hospital staff so that they can be trusted and believed. In order to be trustworthy and trustworthy, the Ponorogo Muslimat Hospital guarantees punctuality in service to patients, because indeed its advantages are fast and on time.

Timeliness in the service is also supported by guaranteed costs in services. RSU Muslimat Ponorogo collaborates with several insurance companies, such as BPJS Kesehatan, BPJS Ketenagakerjaan, and Jasa Raharja. In addition, the Ponorogo Muslimat Hospital also applies fee waivers for people who have an NU member card. Meanwhile, for patients who cannot afford it, the cost can be taken from the hospital employees' infaq. Besides being used for underprivileged patients, the infaq is also distributed for social service and donations for orphans. Thus, in measuring service quality, we must pay attention to the dimensions of assurance (assurance). This dimension consists of indicators, such as the officer providing guarantees on time and guaranteed costs in services.

\section{Empathy}

RSU Muslimat Ponorogo also pays attention to the empathy dimension in improving the service quality. The hospital always tries to establish good communication relationships, understand the needs of patients as customers, and act in the interests of patients. In this case, officers always prioritize the interests of patients without discrimination. They try to provide sincere service with a friendly, polite, polite attitude, and try to understand the patient's wishes. So that in improving the quality of service, the hospital must pay attention to the empathy dimension which consists of indicators such as prioritizing the interests of the patient, serving with a polite, polite, friendly attitude, respecting each patient, and serving without discrimination.

Inhibiting Factors and Supporting Factors for Public Relations Strategy of RSU Muslimat Ponorogo in Improving Service Quality to Patients

In assessing the quality of service at the hospital, the size is not only determined by the serving party but more is determined by the party being served 
or the patient. This is because it is the patient who enjoys the services provided by the hospital. So that the quality of service can be measured based on the expectations of patients in meeting their satisfaction.

Therefore, in the process of improving service quality, there must be inhibiting factors as well as supporting factors that greatly affect the public. Inhibiting factors or supporting factors can arise from within or outside the company. The following describes the inhibiting factors and supporting factors found in activities to improve the quality of servants at the Muslimat Ponorogo Hospital, namely:

\section{Obstacle Factor}

Obstacles or obstacles faced by public relations include: (1) Queuing problems at the registration section and waiting too long for a doctor to be present are one of the causes of services at the Muslimat Ponorogo Hospital being less than optimal, (2) There are several services at the Muslimat Ponorogo Hospital who cannot be served in hospitals and must collaborate with third parties as working partners, such as CT scans, dialysis, and chemotherapy, (3) There are several complaints in parking services due to the lack of parking area which is still a separate problem from year to year for the Ponorogo Muslimat Hospital. On the other hand, the parking lot is not managed by the hospital management, but managed by the outside community, (4) There are several public relations work programs at the Muslimat Ponorogo Hospital from 2018 to 2019 that have not been achieved, such as a social service program that must be implemented for 4 times a year, but only twice. This is due to the lack of human resources (HR) and public relations only as a coordinator. When there is a work program that must be implemented, the party or part that goes into the field is the team in service. Sometimes teams that are supposed to go to the field cannot because they have to hold the burden of other services, (5) The existence of the Corona virus that hit Indonesia, especially the Ponorogo area in early 2020 and caused several activities or public relations work programs at the Ponorogo Muslimat Hospital to be delayed.

\section{Supporting factors}

Apart from inhibiting factors, there are also supporting factors that play a role in improving the quality of patients at the Muslimat Ponorogo Hospital. Based on the theory used by researchers in chapter II, it was found that supporting factors were found in the public relations strategy of the Muslimat Ponorogo Hospital in improving the quality of service to patients. The supporting factor is the presence of an introductory media that is part of the strategy being implemented. The introductory media used include conventional media, namely radio and television, outdoor media, namely billboards and brochures, and new media (internet), namely the internet, social media websites, Facebook, Instagram, Twitter, and YouTube. 


\section{Conclution}

The human relations strategy of RSU Muslimat Ponorogo in improving the quality of service to patients is to maintain a special relationship between people, both internal and external to the company. Internal relations, namely maintaining good relations with employees (employee relations), such as holding in-house training (IHT) activities, special coaching for employees, exercise activities, taking walks, and outbound activities with employees. Meanwhile, external relations, namely maintaining good relationships with customers or patients (customer relations), are manifested in various activities that lead to social care. Such as home visits for posthospitalized patients, treatment for the duafa community, mass circumcision or circumcision for pious children, and cost relief for poor patients.

The community relations strategy of RSU Muslimat Ponorogo in improving the quality of service to patients is to maintain good relations with the community and community around the hospital. This is done by holding activities related to the Ponorogo branch of Nahdlatul Ulama as the owner of the Ponorogo Muslimat Hospital, namely participating in the NU harlah and Muslimat harlah activities. In addition, there are also activities related to the wider community, especially the community, such as health checks for hypertension clubs, health checks with the Terios car club, socialization services at meetings of Muslimat NU women and social services at Sima'an Wednesday Pahing.

The strategy of media relations at RSU Muslimat Ponorogo in improving the quality of service to patients is to use mass media, both print, electronic and new media (internet). This includes health seminars published by the weekly Mataraman media, talk shows on Aswaja radio, as well as NU's harlah and Muslimat harlah on Sakti TV. Meanwhile, other activities carried out are communication in the form of publications through social media such as websites, Facebook, YouTube, Instagram, and Twitter.

There are inhibiting factors and supporting factors for public relations RSU Muslimat Ponorogo in improving the quality of service to patients. The inhibiting factor is the queue problem at the registration section, waiting too long for the doctor's presence, lack of parking area, there are still some services that cannot be served at the hospital and must cooperate with third parties, there are still several public relations work programs at the Muslimat Ponorogo Hospital from the year 2018 to 2019 which was not achieved, and a lack of human resources (HR). While the supporting factor is the introduction of media which is part of the public relations strategy undertaken. The introductory media used include conventional media, namely radio and television, outdoor media, namely billboards, and new media (internet), namely the internet, social media websites, Facebook, Instagram, and YouTube.

The results of this study can be used as input or reference material for the Public Relations of the Muslimat Ponorogo Hospital to maximize and optimize its performance related to programs to be implemented, especially in improving the quality of service to patients. Meanwhile, it is suggested that in the future the 
Muslimat Ponorogo Hospital can complement the existing facilities in the hospital to improve the quality of service.

With this research, it is hoped that the Muslimat Ponorogo Hospital will pay more attention to matters related to optimal service to patients. It is hoped that the public relations at RSU Muslimat Ponorogo will be more aggressive in carrying out promotions, improving the infrastructure of hospital facilities and infrastructure. The results of this research can be used as learning materials or additional references for academics in the same field, namely communication science, especially regarding public relations strategies. However, further studies on public relations strategies also need to be carried out in order to add to the aspects not listed in this research. The next researcher wants to examine more deeply about the strategies carried out by public relations in the hospital in improving the quality of service to patients.

\section{REFERENCES}

Ardial, H. Paradigma dan Model Penelitian Komunikasi.Jakarta: Bumi Aksara, 2015. Arikunto, Suharsimi. Prosedur Penelitian Suatu Pendekatan Praktik.Jakarta: Rineka Cipta, 2006.

Barata, Atep Adya. Dasar-Dasar Pelayanan Prima: Persiapan Membangun Budaya Pelayanan Prima untuk Meningkatkan Kepuasan dan Loyalitas Pelanggan.Jakarta: PT. Elex Media Komputindo, 2003.

Basrowi. Memahami Penelitian Kualitatif.Jakarta: Rineka Cipta, 2008.

Chairunnisak, Syarifah. "Strategi Public Relations Officer dalam Meningkatkan Kualitas Pelayanan Informasi Rumah Sakit Umum Daerah Dr. Zainoel Abidin di Banda Aceh". Universitas Sumatera Utara, 2019.

Cutlip, Scott M. et al.Effective Public Relations. Terj: Tri Wibowo.Jakarta: Kencana, 2006.

Darmastuti, Rini. Media Relations: Konsep, Strategi dan Aplikasi.Yogyakarta: CV Andi Offset, 2012.

Effendy, Onong Uchjana. Human Relations \& Public Relations. Bandung: CV. Mandar Maju, 2009.

Rosdakarya, 2001. . Ilmu Komunikasi Teori Dan Praktik. Bandung: PT Remaja

Ghony, M. Djunaidi. Fauzan Almanshur. Metode Penelitian Kualitatif.Yogyakarta: ArRuzz Media, 2012.

Hadiati S, Nikmah. Public Relations Perspektif Teoritis dalam Menjalin Hubungan dengan Publik. Pasuruan: Lunar Media, 2011.

Irwandy. Efisiensi dan Produktifitas Rumah Sakit: Teori dan Aplikasi Pengukuran dengan

Pendekatan Data Envelopment Analysis.Makasar: CV. Social Politic SIGn, 2019.

Kriyantono, Rachmat. Teori Public Relations Perspektif Barat dan Lokal: Aplikasi

Penelitian dan Praktik.Jakarta: Prenadamedia Group, 2014.

Mahmud, Metode Penelitian Pendidikan.Bandung: CV Pustaka Setia, 2011.

Mamik. Metododologi Kualitatif. Sidoarjo: Zifatama Publisher, 2015. 
Moleong, Lexy J. Metode Penelitian Kualitatif. Bandung: Remaja Rosdakarya, 2005.

Morissan. Manajemen Public Relations: Strategi Menjadi Humas Profesional.Jakarta: Kencana, 2008.

Mu'ah. Kualitas Layanan Rumah Sakit: Terhadap Emosi dan Kepuasan Pasien. Sidoarjo: Zifatama Publisher, 2014.

Mulyawan, Rahman. Birokrasi Dan Pelayanan Publik. Bandung: UNPAD Press, 2016.

Nadie, Lahyanto. Media Massa dan Pasar Modal: Strategi Komunikasi bagi Perusahaan Go Public. Jakarta: Media Center, 2018.

Nawawi, Hadari. Metode Penelitian Bidang Sosial.Yogyakarta: Gadjah Mada University Press, 2007.

Nova, Firsan. Crisis Public Relations: Strategi PR Menghadapi Krisis, Mengelola Isu, Membangun Citra, Dan Reputasi Perusahaan. Jakarta: Rajawali Press, 2011.

Nugrahani, Farida. Metode Penelitian Kualitatif dalam Penelitian Pendidikan Bahasa.Surakarta: Cakra Books, 2014.

Nurtjahjani, Fullchis. Shinta Maharani Trivena. Public Relations: Citra dan Praktek. Malang: Polinema Press, 2018.

Raco, J. R. Metode Penelitian Kualitatif: Jenis, Karakteristik dan Keunggulannya. Jakarta: PT Grasindo, 2010.

Ruslan, Rosady. Metode Penelitian Public Relations dan Komunikasi.Jakarta: PT Rajagrafindo Persada, 2010.

Sedarmayanti. Manajemen Strategi. Bandung: PT Refika Aditama, 2014.

Setyawati, Diana. "Strategi Public Relations dalam Mempertahankan Citra Halal Tourism di Syariah Hotel Solo". Institut Agama Islam Negeri Surakarta, 2017. Soemirat, Soleh. Elvinaro Ardianto. Dasar-dasar Public Relations.Bandung: PT Remaja Rosdakarya, 2012.

Trisna, Lusia. "Strategi Public Relations (PR) dalam Meningkatkan Image Kualitas Pelayanan Kepada Pasien di Rumah Sakit Permata Hati Duri". Universitas Islam Negeri Sultan Syarif Kasim, 2013.

Umar, Husein. Strategic Management in Action. Jakarta: PT Gramedia Pustaka Utama, 2001.

Dokumentasi RSU Muslimat Ponorogo $\underline{\text { https://rs- }}$ muslimatponorogo.com/profil, diakses tanggal 5 Maret 2020. https://rsmuslimatponorogo.com/artikel, diakses 5 Maret 2020. 